\title{
Evaluation methods of sagittal curvatures in invasive examinations of the spine: a systematic review
}

\author{
Métodos de avaliação das curvaturas sagitais em exames \\ invasivos da coluna vertebral: uma revisão sistemática
}

\author{
Bárbara Vendramini Marchetti ${ }^{1}$; \\ Eduardo Raupp ${ }^{2}$, \\ Cláudia Tarragô Candotti ${ }^{3}$
}

\section{RESUMO}

Introdução: A avaliação das curvaturas sagitais da coluna vertebral auxilia na determinação dos padrões posturais dos indivíduos. Objetivo: Revisar sistematicamente os métodos de avaliação das curvaturas sagitais da coluna vertebral no exame de Raios-X descritos em estudos observacionais. Métodos: Foi realizada uma busca sistemática nas bases de dados Scopus, Science, Bireme e Pubmed. Os principais desfechos extraídos foram os métodos utilizados para avaliar as curvaturas torácica e lombar da coluna vertebral no plano sagital através do exame de Raios-X. Para avaliação da qualidade metodológica foi utilizado o checklist de Brink\&, Louw. Resultados: Nos 23 artigos incluídos nessa revisão, encontramos nove métodos diferentes para avaliar as curvaturas sagitais, tais como Cobb (2 ou 4 linhas), Cobb alternativo, Cobb máximo ou não constricto, Raio da curvatura, TRALL, Círculos tangenciais, Tangentes posteriores, Centroides e PR. Os métodos não dependentes dos platôs vertebrais, tais como Centroides, Círculos tangenciais, Cobb alternativo, Raio da curvatura para a coluna torácica; Centroide, Tangente posterior, TRALL e PR para a lombar apresentam iguais ou melhores valores de reprodutibilidade e menor variabilidade de medidas que quando comparados ao ângulo Cobb. Conclusão: Os métodos encontrados mostraram grande correlação com o padrão ouro (ângulo Cobb), tanto para coluna torácica, quanto para a lombar, e podem ser utilizados, em ambos os âmbitos, da pesquisa e da prática clínica, já que apresentam iguais ou melhores valores de reprodutibilidade e menor variabilidade de medidas que quando comparados ao ângulo Cobb.

\section{PALAVRAS-CHAVE}

Avaliação invasiva; Coluna vertebral; Cifose; Lordose.

\footnotetext{
${ }^{1}$ Physical Therapyst, Master in Human Movement Sciences at School of Physical Education of the Universidade Federal do Rio Grande do Sul. Porto Alegre, RS, Brazil, email: barbara.rpg@gmail.com

${ }^{2}$ Chiropractor, Master in Human Movement Sciences at School of Physical Education of the Universidade Federal do Rio Grande do Sul. Porto Alegre, RS, Brazil, eduardorauppdc@yahoo.com.br

${ }^{3}$ Professor on the Post-Graduate Program in Human Movement Sciences at School of Physical Education of the Universidade Federal do Rio Grande do Sul. Porto Alegre, RS, Brazil, email: claudia.candotti@ufrgs.br
} 


\section{ABSTRACT}

Introduction: The evaluation of sagittal spinal curvatures assists in determining the posture of the individual patterns. Objective: Systematically review the methods of evaluationof sagittal spinal curvatures in examining X-rays described in observational studies. Methods: A systematic search was conducted in Scopus databases, Science, Bireme and Pubmed. The mainoutcomes were the methods used to evaluatethe thoracic and lumbar spinal curvatures in the sagittal plane by examining X-rays. To evaluatethe methodological quality a checklist proposed by Brink \&Louw (2011). Results:In the 23 articles included in this review, we found nine different methods to evaluate the sagittal curvatures, such as the Cobb (2 or 4 lines), alternative Cobb, maximum or not constricted Cobb, radius of curvature, TRALL, tangential Circles, posterior Tangent, Centroids and PR. Non-dependent methods of vertebral plateaus, such as Centroids, tangential Circles, alternative Cobb, Radius of curvature of thoracic spine; Centroid, posterior Tangent,TRALL and for lumbar have equal or better reproducibility values and less variability measures compared to the Cobb angle. Conclusion: The proposed methods were highly correlated with the gold standard for both thoracic spine and for the lumbar, these methods are reliable and can be used both in research and in clinical practice, since they have equal or better reproducibility and lower values variability measures than compared the Cobb angle

\section{KEYWORDS}

Invasive evaluation; Spine; Kyphosis; Lordosis. 


\section{INTRODUCTION}

The assessment of sagittal spinal curvatures assists in determining postural patterns of individuals (Čelan et al., 2012). The gold standard for such evaluations are the X-ray examinations lateral-lateral (Zaina et al., 2003) in which the calculations of the Cobb angles are performed, able to quantify the magnitude of these curvatures(Briggs et al., 2007).

However, many critical regarding the Cobb method are described in literature, such as the difficulty in selecting the endplate of the cranial and caudal vertebrae to perform mensuration(Harrison, Harrison, et al., 2001). Another major criticism of this method is the fact that this measure allows only the final information of the curve without knowledge of the segments

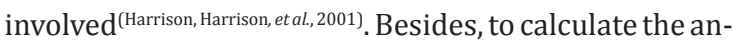
gle of traditional Cobb method the formation of the four lines is required, being the high amount of intra- and inter-observer error (5-10 degrees) another potential source of criticism to the method(Carman et al., 1990).

These criticisms may have encouraged the development of alternatives to a segmental analysis or other ways of evaluating the sagittal plane of the radiographs, such as thetangentofthe posterior vertebralbodies(Bernhardt e Bridwell, 1989), methods using the centroid of vertebrae(Harrison, Donald D et al., 1998; Chen, 1999) and TRALL (Chernukha et al., 1998) method.

Although these methods are well described in the literature, we did not find information on which one of them have lower variability and higher reliability of the measures. Thus, the aim of this study is to systematically review the methods of evaluation of sagittal curvatures of the spine in examining X-rays of children, adolescents, adults and elderly, healthy, with or without postural changes described in observational studies. It is expected that the results of this systematic review may help health-care professionals in choosing the most appropriate method to evaluate with greater accuracy and reliability the sagittal curvatures of the spine in X-rays examinations.

\section{METHODOLOGY}

This review follows the recommendations suggested by the Collaboration Cochrane(Higgins e Green,
2011), with observational studies as eligibility criteria, showing the radiographic evaluation in the sagittal plane of the thoracic and lumbar curvatures of the spine in children, adolescents, adults and elderly, healthy, with or without postural changes, written in English. Therefore, a systematic research was conducted in Scopus databases, Science, Bireme and Pubmed in August 2015. The keywords used were: "Validation Studies" [Publication Type] OR "Reproducibility of Results"[Mesh]" AND "Thoracic Vertebrae"[Mesh] OR "Lumbar Vertebrae"[Mesh] AND "Radiography"[Mesh] AND "Adolescent"[Mesh] OR "Young Adult"[Mesh] OR "Adult"[Mesh] OR "Aged"[Mesh] OR "Elderly"[All Fields] OR "Humans"[Mesh] OR "Human"[All Fields] OR "Child"[Mesh]AND "Kyphosis"[Mesh]OR "Lordosis"[Mesh] OR "sagittal" OR "lateral".

Initially, the studies were selected from reading the titles and abstracts, and articles that had the potential to be included in the research were read and analyzed in full. Afterwards, those who fulfilled all inclusion criteria were finally included. The references of each article included were also investigated in order to find articles not located in the electronic research. All the research procedures, selection, evaluation of quality, data extraction and reading of the articles were performed by two independent evaluators. In case of divergence of views among evaluators, a third evaluator was invited to conduct the evaluation of the article.

The two researchers evaluated independently the full articles included in the review and the extraction of data occurred through a standardized form. The main outcomes from the studies were methods used to evaluate the thoracic and lumbar curvatures of the spine in the sagittal plane through X-rays examinations. Other outcomes were: average value, standard deviation, average differences between measurements, intra- and inter-observer reliability analysis. In case of disagreement among researchers regarding the data derived from studies, it was resolved by consensus between them or by consulting a third more experienced researcher. While the study did not show all the necessary data for the review, the corresponding author was contacted to request the missing data.

To evaluate the methodological quality a checklist proposed by Brink \&, Louw(Brink et al., 2011) (2011) was used, which was designed to test the reliability and 
validity studies. This tool consists of 13 items and it was developed from two scales, the Quality Assessment of Diagnostic Accuracy Studies (QUADAS) and the Quality Appraisal of Diagnostic Reliability Studies (QAREL). The studies were considered high quality if they had $\mathrm{a} \geq 60 \%$ (up to 8) score in the applicable items, according to prior use in other works of the same type(May et al., 2010; Adhia et al., 2013). Two reviewers independently evaluated the methodological quality of the included studies. Any disagreement was discussed between them and whenever the disagreement persisted, a third reviewer was consulted.

Considering the divergence of terminology between the studies, for the validation criteria of the instruments and for facilitating the comparison between the results, the terminology has been standardized in this systematic review as follows: the repeatability was considered as the degree of agreement obtained from evaluations performed on successive instants by the same evalua- tor; intra-rater reproducibility as the degree of reproducibility of the measurements performed by the same rater, varying the time between the collection (with a minimum interval of one day); inter-rater reproducibility and the degree of reproducibility of the measurements made by different observers; and concurrent validity as the agreement between the instrument under test and the instrument considered the gold standard for variable evaluation study(Bipm et al., 2008).

\section{RESULTS}

Initially 1583 articles were found, of these, 278 were excluded because they were duplicates and 1254 did not meet the inclusion criteria. Thus, 51 studies were initially included in this systematic review. After reading in full, 22 studies met the inclusion criteria. Subsequently, their references were analyzed and one more article was added to subsequent data extraction (Figure 1).

Figure 1. Flow chart of selection of items, based on the PRISMA guidelines.

Busca nas bases de dados: Pubmed (342), Scopus (990), Science (12), Bireme (39) Total: 1383

Excluídos: Duplicatas (241)

Artigos selecionados para análise de títulos e resumos: 1142

Excluídos após análise de
títulos e resumos (1092)



Artigos incluídos após leitura do texto completo: 21

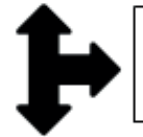

Artigos selecionados a partir da análise das referências bibliográficas: 1

Incluídos na revisão sistemática: 22 
Table 1 shows the evaluation of methodological quality used in this systematic review. Of the 22 studies selected, only two were classified as being of low quality, and, thus, weak scientific evidence.

Table 1. Results of methodological quality of the checklist based on QUADAS and QAREL scales.

\begin{tabular}{|c|c|c|c|c|c|c|c|c|c|c|c|c|c|c|}
\hline \multirow{2}{*}{$\begin{array}{l}\text { Studies-First author } \\
\text { (year) }\end{array}$} & \multicolumn{13}{|c|}{ Criteria Checklist QUADAS and QAREL } & \multirow{2}{*}{$\begin{array}{l}\text { TOTAL } \\
\text { (number) }\end{array}$} \\
\hline & 1 & 2 & 3 & 4 & 5 & 6 & 7 & 8 & 9 & 10 & 11 & 12 & 13 & \\
\hline Andreasen 2007 & $\mathrm{Y}$ & $\mathrm{Y}$ & N/A & $\mathrm{Y}$ & $\mathrm{Y}$ & $\mathrm{Y}$ & $\mathrm{N} / \mathrm{A}$ & $\mathrm{Y}$ & $\mathrm{N} / \mathrm{A}$ & $\mathrm{Y}$ & $\mathrm{N} / \mathrm{A}$ & $\mathrm{Y}$ & $\mathrm{N}$ & 8 \\
\hline Briggs 2006 & $\mathrm{Y}$ & Y & $\mathrm{Y}$ & Y & $\mathrm{Y}$ & $\mathrm{Y}$ & $\mathrm{Y}$ & $\mathrm{Y}$ & Y & Y & $\mathrm{Y}$ & $\mathrm{Y}$ & $\mathrm{Y}$ & 13 \\
\hline Chanplakorn 2011 & $\mathrm{Y}$ & Y & $\mathrm{Y}$ & $\mathrm{Y}$ & N/A & $\mathrm{N}$ & Y & $\mathrm{Y}$ & Y & Y & $\mathrm{Y}$ & $\mathrm{N}$ & $\mathrm{N}$ & 9 \\
\hline Chen 1999 & $\mathrm{Y}$ & Y & $\mathrm{Y}$ & $\mathrm{Y}$ & Y & $\mathrm{N}$ & Y & $\mathrm{Y}$ & $\mathrm{Y}$ & Y & $\mathrm{Y}$ & $\mathrm{N}$ & $\mathrm{Y}$ & 11 \\
\hline Chernukha 1998 & $\mathrm{Y}$ & Y & $\mathrm{Y}$ & $\mathrm{Y}$ & $\mathrm{Y}$ & $\mathrm{N}$ & $\mathrm{Y}$ & $\mathrm{Y}$ & $\mathrm{Y}$ & Y & $\mathrm{Y}$ & $\mathrm{Y}$ & $\mathrm{N}$ & 11 \\
\hline Carvalho 2010 & $\mathrm{Y}$ & Y & N/A & $\mathrm{Y}$ & Y & $\mathrm{Y}$ & N/A & $\mathrm{Y}$ & N/A & $\mathrm{Y}$ & $\mathrm{N} / \mathrm{A}$ & $\mathrm{Y}$ & $\mathrm{N}$ & 8 \\
\hline Gardocki 2002 & $\mathrm{Y}$ & $\mathrm{N}$ & Y & N/A & $\mathrm{N} / \mathrm{A}$ & N/A & $\mathrm{Y}$ & $\mathrm{N} / \mathrm{A}$ & $\mathrm{Y}$ & Y & $\mathrm{Y}$ & $\mathrm{Y}$ & $\mathrm{N}$ & 8 \\
\hline Goh 2000 & $\mathrm{Y}$ & $\mathrm{N}$ & $\mathrm{Y}$ & $\mathrm{N}$ & $\mathrm{N}$ & $\mathrm{N}$ & Y & Y & $\mathrm{Y}$ & Y & $\mathrm{Y}$ & $\mathrm{Y}$ & $\mathrm{Y}$ & 9 \\
\hline Harrison 2001 & $\mathrm{Y}$ & $\mathrm{N}$ & $\mathrm{Y}$ & $\mathrm{Y}$ & $\mathrm{Y}$ & Y & Y & Y & $\mathrm{Y}$ & $\mathrm{Y}$ & $\mathrm{Y}$ & $\mathrm{Y}$ & Y & 12 \\
\hline Harrison 2001 & $\mathrm{Y}$ & Y & $\mathrm{Y}$ & $\mathrm{Y}$ & $\mathrm{Y}$ & $\mathrm{Y}$ & $\mathrm{Y}$ & $\mathrm{Y}$ & $\mathrm{Y}$ & $\mathrm{Y}$ & $\mathrm{Y}$ & $\mathrm{Y}$ & $\mathrm{Y}$ & 13 \\
\hline Hicks 2006 & $\mathrm{Y}$ & Y & $\mathrm{N} / \mathrm{A}$ & $\mathrm{Y}$ & $\mathrm{N} / \mathrm{A}$ & $\mathrm{N}$ & N/A & Y & $\mathrm{N} / \mathrm{A}$ & Y & $\mathrm{N} / \mathrm{A}$ & $\mathrm{Y}$ & $\mathrm{Y}$ & 7 \\
\hline Hong 2010 & $\mathrm{Y}$ & $\mathrm{N}$ & Y & $\mathrm{N}$ & $\mathrm{N}$ & $\mathrm{Y}$ & Y & $\mathrm{Y}$ & Y & Y & Y & $\mathrm{Y}$ & $\mathrm{Y}$ & 10 \\
\hline Hwang 2010 & $\mathrm{Y}$ & Y & $\mathrm{Y}$ & $\mathrm{N}$ & $\mathrm{Y}$ & $\mathrm{N}$ & Y & $\mathrm{Y}$ & $\mathrm{Y}$ & Y & $\mathrm{Y}$ & $\mathrm{Y}$ & Y & 11 \\
\hline Jackson 1998 & $\mathrm{Y}$ & $\mathrm{N}$ & $\mathrm{Y}$ & $\mathrm{Y}$ & $\mathrm{N}$ & $\mathrm{N}$ & $\mathrm{Y}$ & $\mathrm{Y}$ & $\mathrm{Y}$ & $\mathrm{Y}$ & $\mathrm{Y}$ & $\mathrm{Y}$ & $\mathrm{N}$ & 9 \\
\hline Jackson 2000 & $\mathrm{Y}$ & $\mathrm{N}$ & $\mathrm{Y}$ & $\mathrm{Y}$ & $\mathrm{Y}$ & $\mathrm{Y}$ & $\mathrm{Y}$ & $\mathrm{Y}$ & $\mathrm{Y}$ & Y & $\mathrm{Y}$ & $\mathrm{Y}$ & $\mathrm{Y}$ & 12 \\
\hline Lee 2013 & $\mathrm{Y}$ & $\mathrm{N}$ & $\mathrm{Y}$ & $\mathrm{N}$ & $\mathrm{N}$ & $\mathrm{N}$ & $\mathrm{Y}$ & Y & $\mathrm{Y}$ & $\mathrm{Y}$ & $\mathrm{Y}$ & $\mathrm{Y}$ & $\mathrm{Y}$ & 9 \\
\hline Mac Thiong 2007 & $\mathrm{Y}$ & Y & $\mathrm{Y}$ & $\mathrm{N}$ & $\mathrm{N}$ & $\mathrm{N}$ & $\mathrm{Y}$ & Y & $\mathrm{Y}$ & $\mathrm{Y}$ & $\mathrm{Y}$ & $\mathrm{Y}$ & $\mathrm{Y}$ & 10 \\
\hline Pinel-Giroux 2006 & $\mathrm{Y}$ & Y & $\mathrm{Y}$ & $\mathrm{N}$ & $\mathrm{N}$ & $\mathrm{N}$ & Y & Y & $\mathrm{Y}$ & Y & Y & $\mathrm{N}$ & $\mathrm{Y}$ & 9 \\
\hline Polly 1996 & $\mathrm{Y}$ & Y & $\mathrm{Y}$ & $\mathrm{Y}$ & $\mathrm{Y}$ & $\mathrm{Y}$ & $\mathrm{Y}$ & $\mathrm{Y}$ & $\mathrm{Y}$ & Y & $\mathrm{Y}$ & $\mathrm{Y}$ & $\mathrm{Y}$ & 13 \\
\hline Rajnics 2000 & $\mathrm{Y}$ & Y & $\mathrm{N}$ & $\mathrm{N}$ & $\mathrm{N}$ & $\mathrm{N}$ & $\mathrm{N}$ & $\mathrm{N}$ & $\mathrm{N}$ & Y & $\mathrm{N}$ & $\mathrm{Y}$ & $\mathrm{N}$ & 4 \\
\hline Troyanovich 1995 & $\mathrm{Y}$ & $\mathrm{Y}$ & N/A & $\mathrm{Y}$ & $\mathrm{Y}$ & $\mathrm{Y}$ & N/A & $\mathrm{Y}$ & N/A & $\mathrm{Y}$ & $\mathrm{N} / \mathrm{A}$ & $\mathrm{Y}$ & $\mathrm{Y}$ & 9 \\
\hline Troyanovich 1998 & Y & Y & $\mathrm{N} / \mathrm{A}$ & Y & Y & Y & $\mathrm{N} / \mathrm{A}$ & Y & $\mathrm{N} / \mathrm{A}$ & Y & $\mathrm{N} / \mathrm{A}$ & Y & Y & 9 \\
\hline Vacari 2015 & $\mathrm{Y}$ & $\mathrm{Y}$ & Y & N/A & N/A & N/A & Y & N/A & Y & Y & $\mathrm{Y}$ & $\mathrm{Y}$ & $\mathrm{Y}$ & 9 \\
\hline
\end{tabular}

Criteria QUADAS and QAREL: 1. Appropriate description of the sample; 2. Adequate description of the evaluators; 3 . Adequate explanation of the reference standard; 4 . Blinding inter evaluators; 5 . Blinding intra evaluators; 6 . evaluation order of variation; 7. Length of time between the rated test and the reference standard; 8. Length of time between repeated measurements; 9. benchmark Independence of the evaluated test; 10. Adequate description of the evaluated test procedure; 11. Adequate description of the benchmark of the procedure; 12. Explanation of any sample loss; 13 . Appropriate statistical methods. Answers to the criteria: $Y=Y e s ;$ $\mathrm{N}=$ No; N/A= Not Applicable.

Table 2 presents the objective (only those related to some aspect of validation and / or reproducibility), the valuation method used, the methodology and the results of 22 studies included in this review. Nine different methods were found to evaluate the sagittal curvatures, such as: (1) Cobb: angle from the vertebral plateaus $(2$ or 4 lines); (2) Alternative Cobb: uses midway between the corners of the vertebral plateaus of the upper and lower vertebrae; (3) Maximum or not constricted Cobb: angle formed from the upper vertebra (kyphosis) or lower (lordosis) to the most inclined vertebra; (4) Radius of Curvature: the anterior and posterior margins of all vertebrae involved are marked producing an arc, the intersection between the radius of the upper vertebra to the lower vertebra form the angle; (5) TRALL: forming a line from the posterior inferior corner of $\mathrm{S} 2$ to the apex and the other from the posterior superior corner L1 to the apex, the angle is formed by the intersection of these lines; (6) tangential Circles: two arcs (anterior wall of the vertebral bodies) are formed from the apex of each curvature to the beginning or end of it, where from geometric equations form the angle; (7) posterior Tangent: uses the two posterior corners of the upper and lower vertebral bodies, the intersection of these two tangent lines form the angle; (8) Centroid: once the center of each vertebral body is found by the intersection of two diagonal lines formed in the corners of each vertebral body, lines are formed interconnecting the center(s) of upper and lower vertebra(e); (9) PR (pelvic radius): angle formed between the PR line (line formed between the hip axis and S1) and another line along the lower plateau of T12 or upper plateau of L1. 
Table 2. Summary of 22 studies included in this systematic review.

\begin{tabular}{|c|c|c|c|}
\hline $\begin{array}{l}\text { First author } \\
\text { (year) }\end{array}$ & Objective & Methodology & Results \\
\hline $\begin{array}{l}\text { Andreasen } \\
(2007)\end{array}$ & $\begin{array}{l}\text { Reproducibility intra- and } \\
\text { inter-rater of lumbar lordosis }\end{array}$ & $\begin{array}{l}\mathrm{n}=22, \text { average age } \\
49,5 \text { years old. } \\
\mathrm{X} \text {-Ray - Cobb }(2 \\
\text { lines) } \mathrm{L} 1-\mathrm{S} 1 .\end{array}$ & $\begin{array}{l}\text { Median }=53^{\circ} \text {. } \\
\text { Average of differences between intra- and } \\
\text { inter-rater }=\text { close to zero. }\end{array}$ \\
\hline \multirow[t]{3}{*}{ Briggs (2007) } & $\begin{array}{l}\text { Validity and reproducibility } \\
\text { of kyphosis. }\end{array}$ & $\begin{array}{l}\mathrm{n}=31 \text { elderly } \\
\text { women. X-ray. }\end{array}$ & $\begin{array}{l}\text { Average and standard deviation of Cobb T1 } \\
-\mathrm{T} 12=55,9^{\circ}\left(13,3^{\circ}\right) \text { and Centroid }= \\
54,9^{\circ}\left(11,7^{\circ}\right) .\end{array}$ \\
\hline & & $\begin{array}{l}\text { Cobb (4 lines) } \\
\text { T1-T12, Centroid } \\
\text { T1-T12. }\end{array}$ & $\begin{array}{l}\text { Inter: } \mathrm{ICC}=0,83-0,99 \text { with } \mathrm{SEM}=2,18-4 \text {. } \\
\text { Higher SEM was of Cobb. Intra: ICC }=0,98 \text { - } \\
0,99 \text { with SEM=0,9-1,3. }\end{array}$ \\
\hline & & & $\begin{array}{l}\text { Pearson of Cobb T1-T12 with Centroid } \\
r=0,84(p<0,005)\end{array}$ \\
\hline \multirow[t]{3}{*}{$\begin{array}{l}\text { Chanplakorn } \\
\text { (2011) }\end{array}$} & $\begin{array}{l}\text { Reproducibility intra- and } \\
\text { inter-rater of lumbar lordosis }\end{array}$ & $\begin{array}{l}\mathrm{n}=100, \text { average } \\
\text { age } 33,3 \text { years old. } \\
\text { X-Rays. Cobb (4 } \\
\text { lines) T12-S1, } \\
\text { PR-T12. }\end{array}$ & $\begin{array}{l}\text { Average and standard deviation of Cobb } \\
\text { T12-S1 }=54,7^{\circ}\left(9,9^{\circ}\right) \text { and PR T12 }=92,4^{\circ} \\
\left(8,2^{\circ}\right) \text {. }\end{array}$ \\
\hline & & & Inter ofCobb: ICC = 0,992. \\
\hline & & & Inter of PR: ICC=0,968. \\
\hline \multirow[t]{4}{*}{ Chen (1999) } & $\begin{array}{l}\text { Validity and reproducibility } \\
\text { intra- and inter-rater of } \\
\text { lumbar lordosis }\end{array}$ & $\begin{array}{l}\mathrm{n}=16 \text {, average age } \\
28,6 \text { years } \\
\text { old. X-ray. Cobb } \\
\text { (4 lines) L1-L5 } \\
\text { and L1-S1, } \\
\text { Centroid L1-L5. }\end{array}$ & $\begin{array}{l}\text { Average of Cobb L1-L5=35, } 8^{\circ} ; \text { Cobb L1- } \\
\text { S1 }=50,4^{\circ} \text { and Centroid L1-L5 }=35,3^{\circ} \text {. }\end{array}$ \\
\hline & & & $\begin{array}{l}\text { Mean absolute difference: (1) Intra of Cobb } \\
\text { L1-L5=2 } 2^{\circ} \text { Cobb L1-S1 }=2,2^{\circ} \text { and Centroid } \\
\text { L1-L5 }=1,6^{\circ} ; \text { (2) Inter of Cobb L1-L5 }=4^{\circ} ; \\
\text { Cobb L1-S1 }=4,8^{\circ} \text { and Centroid L1-L5 }=1,3^{\circ} .\end{array}$ \\
\hline & & & $\begin{array}{l}\text { ICC: (1) Intra of Cobb L1-L5=0,942; Cobb } \\
\text { L1-S1=0,938 and Centroid L1-L5=0,948; } \\
\text { (2) Inter of Cobb L1-L5=0,826; Cobb } \\
\text { L1-S1=0,784 and Centroid L1-L5=0,903. }\end{array}$ \\
\hline & & & $\begin{array}{l}\text { Pearson of Centroid with Cobb L1-L5: } \\
\mathrm{r}=0,732 \text { and with Cobb L1-S1: } \\
\mathrm{r}=0,622(\mathrm{p}<0,005)\end{array}$ \\
\hline $\begin{array}{l}\text { Chernukha } \\
\text { (1998) }\end{array}$ & $\begin{array}{l}\text { Reproducibility intra- and } \\
\text { inter-rater of lumbar lordosis }\end{array}$ & $\begin{array}{l}n=199 \text {, average } \\
\text { age } 14,8 \text { years old. } \\
\text { X-ray. }\end{array}$ & $\begin{array}{l}\text { Average and standard deviation of } \\
\text { TRALL }=46,46^{\circ}\left(7,53^{\circ}\right) ; \operatorname{Cobb}=52,4^{\circ} \\
\left(12,43^{\circ}\right) \text {. }\end{array}$ \\
\hline
\end{tabular}




\begin{tabular}{|c|c|c|c|}
\hline & & $\begin{array}{l}\text { Cobb (4 lines) } \\
\text { L1-S1, TRALL } \\
\text { L1-S2. }\end{array}$ & $\begin{array}{l}\text { Fischer test showed that TRALL is more } \\
\text { reproducible than Cobb. Pitman coefficient } \\
\text { showed low error between the intra-rater } \\
\text { measures }(\mathrm{p}=0.044 \text { to } 0.358) \text {. }\end{array}$ \\
\hline \multirow{3}{*}{ Carvalho (2010) } & & $\mathrm{n}=8$, average age & \\
\hline & $\begin{array}{l}\text { Reproducibility of lumbar } \\
\text { lordosis. }\end{array}$ & $\begin{array}{l}\text { 26,75 years old. } \\
\text { X-ray. ( } 4 \text { lines) } \\
\text { L1-S1. }\end{array}$ & $\begin{array}{l}\text { Average and standard deviation of } \\
\operatorname{Cobb}=63^{\circ}\left(15^{\circ}\right)\end{array}$ \\
\hline & & & $\begin{array}{l}\text { Difference between measures varied from } \\
0,1^{\circ} \text { to } 0,5^{\circ} \text { with the standard deviation of } \\
2,26^{\circ} \text {. }\end{array}$ \\
\hline \multirow[t]{2}{*}{$\begin{array}{l}\text { Gardocki } \\
(2002)\end{array}$} & \multirow[t]{2}{*}{$\begin{array}{l}\text { Validity of lordosis } \\
\text { measurements. }\end{array}$} & $\begin{array}{l}\mathrm{n}=28, \text { average age } \\
52 \text { years old. } \\
\text { X-ray. Cobb ( } 4 \\
\text { lines) T1-T12, } \\
\text { L1-S1, PR-L1. }\end{array}$ & $\begin{array}{l}\text { Average and standard deviation of Cobb } \\
\mathrm{L} 1-\mathrm{S} 1=50^{\circ}\left(14,3^{\circ}\right) ; \text { Cobb T1-T12=46,5 } \\
\left(15,9^{\circ}\right) .\end{array}$ \\
\hline & & & $\begin{array}{l}\text { Pearson of PR-L1 with Cobb L1-S1: } r=0,82 \\
(\mathrm{p}<0,000001) \text {. }\end{array}$ \\
\hline \multirow[t]{7}{*}{ Goh (2000) } & $\begin{array}{l}\text { Validity and reproducibility } \\
\text { of kyphosis. }\end{array}$ & $\begin{array}{l}\mathrm{n}=93, \text { average age } \\
58,8 \text { years old. CT } \\
\text { in post mortem. } \\
\text { Radius of } \\
\text { curvature T4-T9, } \\
\text { Cobb (4 lines) } \\
\text { T4-T9 and } \\
\text { alternative Cobb } \\
\text { T4-T9. }\end{array}$ & $\begin{array}{l}\text { Traditional Cobb vs alternative Cobb } \\
\mathrm{r} 2=0,98, \mathrm{p}<0,001\end{array}$ \\
\hline & & & $\begin{array}{l}\text { Traditional Cobb vs Radius of } \\
\text { curvature: } \mathrm{r} 2=0,81 \text {. }\end{array}$ \\
\hline & & & $\begin{array}{l}\text { Alternative Cobb vs Radius of } \\
\text { curvature: } r 2=0,84 \text {. }\end{array}$ \\
\hline & & & $\begin{array}{l}\text { Correlation between Cobb and Alternative } \\
\text { Cobb with the normalized data: } r 2=0,83 \text {. }\end{array}$ \\
\hline & & & ICC of Radius of curvature $=0,95$. \\
\hline & & & ICC of $\mathrm{Cobb}=0,82$ \\
\hline & & & ICC of Alternative Cobb $=0,97$. \\
\hline Harrison (2001) & $\begin{array}{l}\text { Reproducibility intra-rater of } \\
\text { lumbar lordosis }\end{array}$ & $\begin{array}{l}\mathrm{n}=30 \text {, average age } \\
28 \text { years old. } \\
\text { X-ray. Centroid } \\
\text { L1-S1, }\end{array}$ & 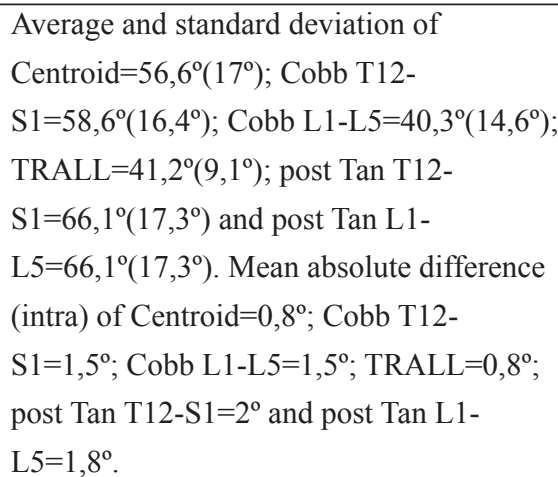 \\
\hline
\end{tabular}




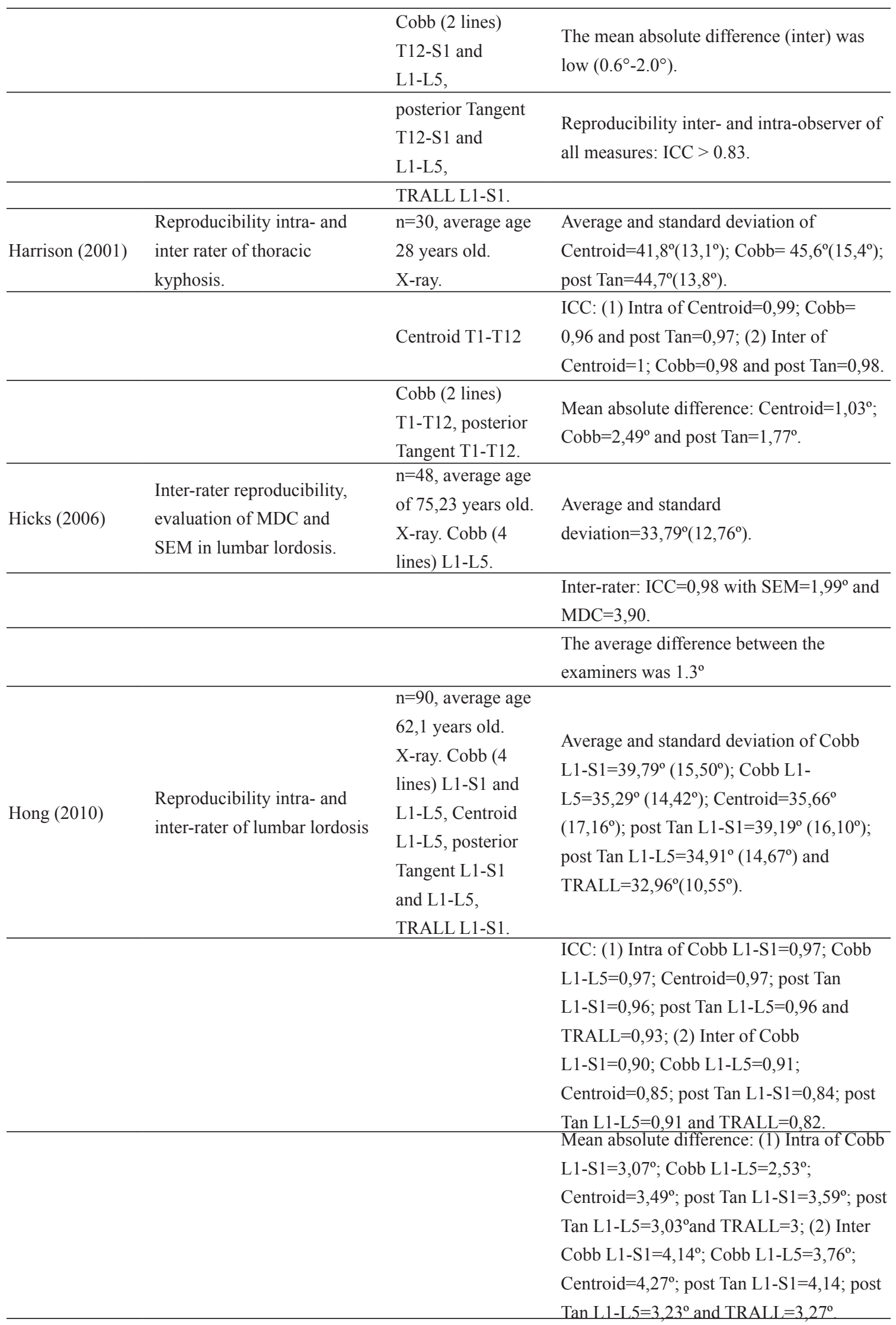




\begin{tabular}{|c|c|c|c|}
\hline \multirow{8}{*}{ Hwang (2010) } & \multirow{8}{*}{$\begin{array}{l}\text { Reproducibility intra- and } \\
\text { inter-rater of lumbar lordosis }\end{array}$} & $\mathrm{n}=36$, average age & \multirow{8}{*}{$\begin{array}{l}\text { Average of Cobb T12-S1 }=41,51^{\circ} ; \text { Cobb } \\
\text { L1-L5 }=26,97^{\circ} \text {; Centroid }=39,87^{\circ} \text {; post Tan } \\
\text { T12-S1 }=45,85^{\circ} \text { and post Tan L1-L5 }=18,82^{\circ} .\end{array}$} \\
\hline & & 39,6 years old. & \\
\hline & & X-ray. Cobb (4 & \\
\hline & & lines) $\mathrm{T} 12-\mathrm{S} 1$ and & \\
\hline & & L1-L5,Centroid & \\
\hline & & T12-S1, posterior & \\
\hline & & Tangent T12-S1 & \\
\hline & & and L1-L5. & \\
\hline & & & ICC: (1) Intra of Cobb \\
\hline & & & $\mathrm{T} 12-\mathrm{S} 1=0,945-0,984 ; \mathrm{Cobb}$ \\
\hline & & & L1-L5 $=0,936-0,984 ;$ Centroid $=0,938-0,996 ;$ \\
\hline & & & post Tan $\mathrm{T} 12-\mathrm{S} 1=0,968-0,992$ and post Tan \\
\hline & & & L1-L5 $=0,966-0,985 ;$ (2) Inter of Cobb \\
\hline & & & $\mathrm{T} 12-\mathrm{S} 1=0,807-0,765 ; \mathrm{Cobb}$ \\
\hline & & & L1-L5 =0,499-0,781; Centroid $=0,893-0,881$; \\
\hline & & & post Tan T12-S1=0,861-0,833 and post Tan \\
\hline & & & L1-L5=0,915-0,892. \\
\hline & & & $\mathrm{SEM}<2^{\circ}$ for Cobb T12-S1, Cobb L1-L5 and \\
\hline & & & post Tang L1-L5. \\
\hline & & & $\mathrm{SEM}<2,3^{\circ}$ for post Tang T12-S1. \\
\hline & & & $\mathrm{SEM}>2,3^{\circ}$ for Centroid. \\
\hline & & & Control group SEM $<2,2^{\circ}$ in all methods. \\
\hline & & $\mathrm{n}=50$, average age & \\
\hline & Reproducibility intra- and & of 39,4 years old. & Average and standard deviation of Cobb \\
\hline Jackson (1998) & inter-rater of kyphosis and & X-ray. Cobb (4 & $\mathrm{T} 1-\mathrm{T} 12=47^{\circ}\left(9,72^{\circ}\right)$ and Cobb L1- \\
\hline & lumbar lordosis. & lines) T1-T12 and & $\mathrm{S} 1=62,1^{\circ}\left(10,8^{\circ}\right)$ \\
\hline & & L1-S1. & \\
\hline & & & Pearson: Intra $=0,93-0,96$ and Inter of Cobb \\
\hline & & & $\mathrm{T} 1-\mathrm{T} 12=0,89$ and Cobb L1-S1 $=0,91$ \\
\hline & & $\mathrm{n}=20$, average age & Average and standard deviation of Cobb \\
\hline Jackson $(2000)$ & Keproducibility intra- and & of 40 years old. & $\mathrm{T} 1-\mathrm{T} 12=44^{\mathrm{o}}\left(9,4^{\circ}\right) ;$ Cobb T12-S1=60,5 \\
\hline (2) & kyphosis & A-ray. Couv & $\left(15,5^{\circ}\right) ;$ Cobb L1-S1=61, $5^{\circ}\left(13,3^{\circ}\right) ;$ PR- \\
\hline & & L1-S1, PR-T12, & $\mathrm{T} 12=92,5^{\circ}\left(10,6^{\circ}\right)$ and PR-L1 $=93^{\circ}\left(9,2^{\circ}\right)$ \\
\hline & & & ICC: (1) Intra of Cobb T1-T12=0,63-0,86; \\
\hline & & & Cobb T12-S1=0,94-0,99; Cobb \\
\hline & & & $\mathrm{L} 1-\mathrm{S} 1=0,97 ; \mathrm{PR}-\mathrm{T} 12=0,90-0,97$ and \\
\hline & & PR-L1. & PR-L1=0,94- 0,99; (2) Inter of Cobb \\
\hline & & & $\mathrm{T} 1-\mathrm{T} 12=0,81-0,86 ; \mathrm{Cobb}$ \\
\hline & & & T12-S1=0,96-0,98; Cobb L1-S1=0,95-0,98; \\
\hline & & & PR-T12=0,96-0,98 and PR-L1=0,98-0,99. \\
\hline & & & Average and standard deviation of Cobb \\
\hline & Renroducibility intra- and & $\mathrm{n}=91$, average age & $\mathrm{L} 1-\mathrm{S} 1=33,1^{\circ}\left(11,3^{\circ}\right) ;$ Cobb L1- \\
\hline Lee (2013) & inter-rater of lumbar lordosis & 44,3years old. & L5 $=23,1^{\circ}\left(11,7^{\circ}\right) ;$ Centroid $=25,3^{\circ}\left(11,2^{\circ}\right)$ \\
\hline & & X-rays. & post Tan L1-S1=43 ${ }^{\circ}\left(11,1^{\circ}\right)$; post Tan L1- \\
\hline & & & $\mathrm{L} 5=18,7^{\circ}\left(11,3^{\circ}\right)$ and $\operatorname{TRALL}=29,3^{\circ}\left(8,1^{\circ}\right)$. \\
\hline
\end{tabular}




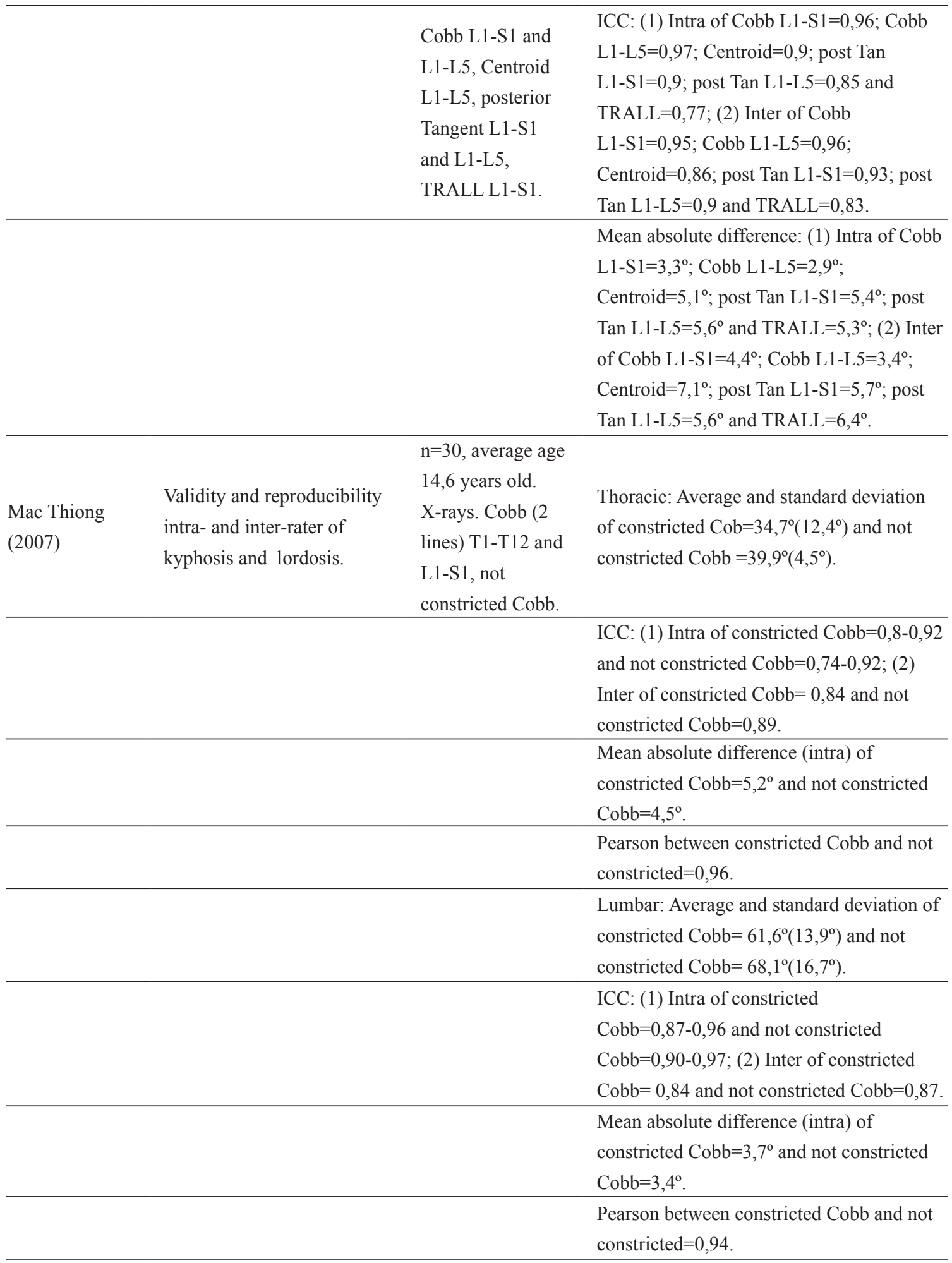




\begin{tabular}{|c|c|c|c|}
\hline \multirow{8}{*}{$\begin{array}{l}\text { Pinel-Giroux } \\
(2006)\end{array}$} & \multirow[b]{2}{*}{$\begin{array}{l}\text { Validity and reproducibility } \\
\text { of kyphosis and lordosis. }\end{array}$} & \multirow[b]{2}{*}{$\begin{array}{l}\mathrm{n}=30, \text { average age } \\
14,6 \text { years } \\
\text { old. X-ray. Cobb } \\
\text { ( } \mathrm{T} 1, \mathrm{~S} 1 \text { to more } \\
\text { inclined vertebra) } \\
\text { maximum, } \\
\text { tangential circles. }\end{array}$} & \multirow[b]{2}{*}{$\begin{array}{l}\text { Lumbar: Average and standard deviation of } \\
\text { Cobb } \max =67,61^{\circ}\left(16,4^{\circ}\right) \text { and tan } \\
\operatorname{cir}=62,5^{\circ}\left(17,8^{\circ}\right)\end{array}$} \\
\hline & & & \\
\hline & & & $\begin{array}{l}\text { Mean absolute difference of Cobb } \\
\max =3,3^{\circ} \text { and } \tan \operatorname{cir}=5,3^{\circ} . \mathrm{ICC}:(1) \text { Intra of } \\
\text { Cobb } \max =0,97 \text { and tan } \operatorname{cir}=0,88,(2) \text { Inter } \\
\text { of Cobb } \max =0,77 \text { and } \tan \operatorname{cir}=0,94 \text {. }\end{array}$ \\
\hline & & & $\begin{array}{l}\text { Pearson: (1) between the measures of Cobb } \\
\max =0,94 \text { and } \tan \operatorname{cir}=0,94 ;(2) \text { between } \\
\text { Cobb max and } \tan \operatorname{cir}=0,88 \text {. }\end{array}$ \\
\hline & & & $\begin{array}{l}\text { Thoracic: Average and standard deviation } \\
\text { of Cobb } \max =40,6^{\circ}\left(12^{\circ}\right) \text { and tan } \\
\operatorname{cir}=36,3^{\circ}\left(11,7^{\circ}\right)\end{array}$ \\
\hline & & & $\begin{array}{l}\text { Mean absolute difference of Cobb } \\
\max =4,5^{\circ} \text { and } \tan \operatorname{cir}=4^{\circ} . \text { ICC (1) Intra of } \\
\text { Cobb } \max =0,88 \text { and tan } \operatorname{cir}=0,94 ; \text { ( } 2 \text { ) Inter } \\
\text { of Cobb } \max =0,85 \text { and tan } \operatorname{cir}=0,94 \text {. }\end{array}$ \\
\hline & & & $\begin{array}{l}\text { Pearson: }(1) \text { between the measures of Cobb } \\
\max =0,84 \text { and } \tan \operatorname{cir}=0,91 ;(2) \text { between } \\
\text { Cobb } \max \text { and } \tan \operatorname{cir}=0,93 \text {. }\end{array}$ \\
\hline & & & $\begin{array}{l}\text { Test } t \text { did not show differences between } \\
\text { measurements. }\end{array}$ \\
\hline Polly (1996) & $\begin{array}{l}\text { Reproducibility intra- and } \\
\text { inter-rater of lumbar lordosis }\end{array}$ & $\begin{array}{l}\text { n=60. X-rays. } \\
\text { Cobb (4 lines) } \\
\text { T12-S1,L1-S1,L1- } \\
\text { L5,T12-L5. }\end{array}$ & $\begin{array}{l}\text { ICC: (1) Intra of Cobb L1-L5=0,87-0,95; } \\
\text { Cobb L1-S1=0,83-0,94; Cobb } \\
\text { T12-L5=0,83-0,96 and Cobb } \\
\text { T12-S1=0,85-0,95; (2) Inter of Cobb } \\
\text { L1-L5=0,90-0,92; Cobb L1-S1=0,81-0,88; } \\
\text { Cobb T12-L5=0,84-0,92 and Cobb } \\
\text { T12-S1=0,83-0,87. }\end{array}$ \\
\hline Rajnics (2000) & $\begin{array}{l}\text { Reproducibility intra-rater of } \\
\text { kyphosis and lordosis. }\end{array}$ & $\begin{array}{l}\mathrm{n}=30, \text { average age } \\
34,3 \text { years old. } \\
\text { X-rays. Cobb ( } 4 \\
\text { lines) T4-T12 and } \\
\text { L1-L5. }\end{array}$ & $\begin{array}{l}\text { The less reproducible measure was Cobb } \\
\text { T4-T12 with the standard deviation of }=6,5^{\circ} \text {. }\end{array}$ \\
\hline \multirow[t]{3}{*}{$\begin{array}{l}\text { Troyanovich } \\
\text { (1995) }\end{array}$} & $\begin{array}{l}\text { Reproducibility intra- and } \\
\text { inter-rater of lumbar }\end{array}$ & $\begin{array}{l}\mathrm{n}=35 . \text { X-ray. } \\
\text { posterior Tangent } \\
\text { L1-L5. }\end{array}$ & $\begin{array}{l}\text { Average and standard } \\
\text { deviation }=35,65^{\circ}\left(10,85^{\circ}\right)\end{array}$ \\
\hline & & & $\begin{array}{l}\text { Pearson of first and second evaluation }=0,98 \\
\text { with } \mathrm{SEM}=1,53^{\circ}\end{array}$ \\
\hline & & & $\begin{array}{l}\text { ICC: }(1) \text { Intra }=0,98 \text { with } \mathrm{SEM}=1,48^{\circ}-1,58^{\circ} \text {, } \\
\text { (2) Inter }=0,98 \text { with } \mathrm{SEM}=1,66^{\circ} .\end{array}$ \\
\hline
\end{tabular}




\begin{tabular}{|c|c|c|c|}
\hline & & & repeatability $=0,98$ with $\mathrm{SEM}=1,49^{\circ}-1,6^{\circ}$. \\
\hline \multirow{10}{*}{$\begin{array}{l}\text { Troyanovich } \\
\text { (1998) }\end{array}$} & \multirow{3}{*}{$\begin{array}{l}\text { Reproducibility intra- and } \\
\text { inter-rater of lumbar }\end{array}$} & \multirow{3}{*}{$\begin{array}{l}\mathrm{n}=50 . \text { X-rays. } \\
\text { Cobb T12-S1, }\end{array}$} & Average and standard deviation of \\
\hline & & & $\operatorname{Cobb}=60,09^{\circ}\left(9,36^{\circ}\right)$ and post \\
\hline & & & $\operatorname{Tan}=39,98^{\circ}\left(9,41^{\circ}\right)$ \\
\hline & & \multirow{3}{*}{$\begin{array}{l}\text { posterior Tangent } \\
\text { L1-L5. }\end{array}$} & ICC: (1) intra of Cobb $=0,88-0,95$ and post \\
\hline & & & $\operatorname{Tan}=0,95-0,97 ;(2)$ Inter of $\mathrm{Cobb}=0,83-0,92$ \\
\hline & & & and post $\operatorname{Tan}=0,96-0,98$ \\
\hline & & & SEM (1) Intra of Cobb $=1,99^{\circ}-3,32^{\circ}$ and \\
\hline & & & post $\operatorname{Tan}=1,47^{\circ}-1,88^{\circ} ;(2)$ Inter of \\
\hline & & & Cobb $=2,67^{\circ}-3,78^{\circ}$ and post $\operatorname{Tan}=1,40^{\circ}-$ \\
\hline & & & $1,84^{\circ}$ \\
\hline \multirow{7}{*}{ Vacari (2015) } & \multirow{7}{*}{ Validity of lumbar curvature } & \multirow{7}{*}{$\begin{array}{l}\text { n=58. X-rays. } \\
\text { Cobb L1-S1, } \\
\text { Centroid, posterior } \\
\text { Tangent L1-S1 } \\
\text { and L1-L5, } \\
\text { TRALL }\end{array}$} & Pearcon Cohb I 1_S1 and. \\
\hline & & & Pearson Cobb L1-S 1 and: \\
\hline & & & -cenatrord. $0,011(p<0,001)$ \\
\hline & & & - Tangent Post L1-L5:0,467 (P<0,001) \\
\hline & & & -Tangent Post L1-S1: 0,548 (p<0,001) \\
\hline & & & -TRALL: $0,693(\mathrm{p}<0,001)$ \\
\hline & & & \\
\hline
\end{tabular}

Most studies evaluated subjects with an average age from 26 years. Only 2 studies showed individuals with an average age below 20 years(Chernukha et al., 1998; Pinel-Giroux, F.-M. et al., 2006). Regarding the reproducibility of the methods, the studies showed results ranging from moderate to excellent reproducibility. The validity of articles (Table 2) showed high correlation of the proposed method with the gold standard(Goh et al., 2000; Rajnics et al., 2001; Gardocki et al., 2002; Pinel-Giroux, F.-M. et al., 2006; Briggs et al., 2007; Mac-Thiong et al., 2007).

\section{DISCUSSION}

This systematic review aimed to analyze the methods of evaluation of sagittal spinal curvatures in the X-ray examinations described in observational studies, in order to assist health professionals in choosing the most appropriate method to evaluate with greater accuracy and reliability sagittal curvature of the spine. In an organizational way, the discussion was divided according to the sagittal curvature of the spine evaluated: thoracic and lumbar region.

The methods of global evaluation of thoracic region found in this review were: Cobb method (with the following selected vertebral levels: T1-T12, T4-T9, T12-T4), alternative Cobb T4-T9, maximum or not constricted Cobb (T1 to the most inclined vertebrae), Radius of cur- vature T4-T9, tangential circles, posterior tangent (T1-T12, the curvature apex) and Centroid T1-T12. Of these, the most commonly used method is the angle of Cobb T1-T12(Jackson et al., 1998b; Jackson et al., 2000a; Harrison, Harrison, et al., 2001; Gardocki et al., 2002; Briggs et al., 2007; Mac-Thiong et al., 2007). For the most part, these methods were evaluated on matters of validity, reproducibility inter- and intra-observer.

In the studies that reported data on the reproducibility, the ICC values (Intraclass Correlation Coefficient) intra- and inter-rater were higher than 0.75 , which according to Shrout, Fleiss(Shrout e Fleiss, 1979) (1986) are considered excellent (Jackson et al., 1998b; Harrison, Harrison, et al., 2001; Gardocki et al., 2002; Briggs et al., 2007). The exceptions were the studies of Jackson (2000)(Jackson et al., 2000a) and Mac Thiong (2007) (Mac-Thiong et al., 2007), who found an intra-rater ICC of 0.63 and 0.74 for Cobb T1-T12. The authors report that the greatest difficulty is the T1 scanning, attributing the lower reproducibility of the overlapping shoulders in X-ray examinations, making it difficult to identify and scan of the plateaus T1 vertebra in X-Ray images(Jackson et al., 2000a; Mac-Thiong et al., 2007). Thus, the upper limit of vertebrae related to the curvature may change according to the above changes, so the Cobb does not seem to be the best evaluation method.

Most studies estimate the ICC values, however, not all show the values of the SEM (Standard Error of Mea- 
surement) or the MDC (Minimum Detectable Change) to examine the accuracy of methods, because the method can have high reproducibility, but goes along with a high error as well so its interpretation may be questioned. Therefore, the SEM value is also an indication of the reproducibility of measure, this is, the lower the SEM is the more reproducible is the method analyzed. Briggs (2007)(Briggs et al., 2007) was the only study which presented these values, being the higher SEM that one which refers to the inter-rater reproducibility of the Cobb angle T1-T12 (4으).

Concerning the measure values and standard deviation (SD), the Cobb T1-T12 and constricted Cobb showed higher DP values when compared, respectively, to the Centroid method T1-T12(Briggs et al., 2007) and not constricted Cobb(Mac-Thiong et al., 2007). It is worth mentioning that, the lower the standard deviation is, the lower the variability of the measure is, therefore, combined with other aspects concerning the measures, it is essential that also such values are also analyzed in order to identify what is the most appropriate method to be used in clinical practice and scientific research.

The Cobb method is very sensitive to changes in contour and concavity and degeneration of plateaus, so it may show some mistakes which tend to overestimate the value of the curvature. This can be identified, for example, in the evaluation of the thoracic kyphosis in the population with osteoporosis or with Scheuermann disease, whose vertebrae are shown in wedge shape; or in cases of vertebral fractures, in which the selection of the terminal vertebra is inconsistent, and there is great difficulty in identifying the plateausterminal (Troyanovich et al., 1998; Chen, 1999; Goh et al., 2000; Harrison, Harrison, et al., 2001; Briggs et al., 2007; Hong et al., 2010). Moreover, in the calculation of T1-T12 Cobb angle, errors may come because of the impaired view, particularly in too brightimages(Briggs et al., 2007), so, most often other vertebral limits are chosen.

Also in this idea, Pinel-Giroux (2006)(Pinel-Giroux, F. M. et al., 2006) believes that the Cobb method does not have the capacity to evaluate the real global curvature because it determines fixed vertebrae as their levels to the angulation. In an attempt to correct this limitation, the authors used the maximum Cobb for comparison with the tangential circles. This method, on the other hand, provides a geometric model based on the curvature as a whole, apart from that is not influenced by the architecture of the plateaus or intervertebral discs. Another advantage is the visualization in radiographic images, particularly in the thoracic spine in the anterior part of vertebral bodies is more easily visible, a fact which contributes to better reproducibility(Hong et al., 2010) values.

Chen (1999)(Chen, 1999) reports that the superiority of the Centroid is the use of four vertebrae for the angulation, not being dependent on the plateaus, which increases the reproducibility of the method in question(Harrison, D. D. et al., 1998), corroborating Briggs (2007)(Briggs et al., 2007), who reaffirms this benefit in his work and justifies the use of the Centroid in people with kyphosis above 58,25을 being, therefore, an advantageous alternative for people with osteoporosis.

Regarding the studies that tested the concurrent validity of data between a new method and Cobb (Goh et al., 2000; Pinel-Giroux, F. M. et al., 2006; Briggs et al., 2007; Mac-Thiong et al., 2007), the lowest correlation coefficient $(r$ ) found was in the study of Briggs (2007)(Briggs et al., 2007). In this study, the authors correlated the T1-T12 Cobb with T1-T12 Centroid $(r=0.84)$ in a sample of women with osteoporosis, identifying poor correlation between Cobb and Centroid of 58,25 in greater kyphosis, because the Cobb is affected by plateaus terminals of the vertebrae, which may have fractures, resulting in higher angulation. In contrast, the highest value of correlation found was in the study of Goh (2000) (Goh et al., 2000), which the $r$ was 0.98 , which correlated the results of Cobb $\mathrm{T} 4$ to $\mathrm{T} 9$ to alternative Cobb T4, arguing that the latter method seems to be more recommended for being simpler and does not take into account the deformation of the vertebral plateaus in their formation. Goh (2000) (Goh et al., 2000) concluded in his study that, due to the simplicity of the method and ease in in viewing plateaus, alternative Cobb T4-T9, or even the Radius of curvature T4, T9 should be used to evaluate the thoracic curvature of individuals with normal or increased kyphosis, since it has no good correlation with Cobb in subjects with kyphosis lower than $20^{\circ}$.

For the lumbar region, the evaluation methods found in this review were: Cobb method (with the following selected vertebral levels: L1-L5, L1-S1, T12-S1, T12-L5), maximum or not constricted Cobb (S1 to the most inclined vertebrae), tangential Circles, posterior 
Tangent (L1-S1, T12-S1, the curvature apex), Centroid (L1-L5, L1-S1, T12-S1), TRALL (L1-S1, L1-S2) and PR (T12, L1). For the most part, these methods were evaluated on questions of validity, reproducibility inter- and intra-observer. Of these, the most commonly used method is the angle of Cobb-L1 S1(Polly Jr et al., 1996; Chernukha et al., 1998; Jackson et al., 1998b; Chen, 1999; Jackson et al., 2000a; Gardocki et al., 2002; Andreasen et al., 2007; Mac-Thiong et al., 2007; Hong et al., 2010; Lee et al., 2013a; Vacari et al., 2015).

In general, for all methods, in the lumbar region, in the category of intra and inter-raters reproducibility, the ICC values were higher than 0.75 (excellent), except for the study of Hwang (2010)(Hwang et al., 2010) which found that values of 0.499 in Cobb L1-L5 inter-rater. The author attributes this finding to the fact that the population evaluated is in patients with spondylolisthesis and may make changes in the terminals plateaus architecture, suggesting the use of Centroid and posterior Tangents methods. Mac Thiong (2007)(Mac-Thiong et al., 2007) states that individuals with high degree of spondylolisthesis show remodeling and bulging of S1 vertebra, increasing the complexity and accuracy in identifying the terminal plate in the assessment of the lumbar spine. This difficulty in visualizing the plateaus is also found in children, especially if they have scoliosis.

Among the studies included in this systematic review, only Hicks (2006)(Hicks et al., 2006), when evaluating the Cobb angle L1-L5, has presented together SEM and MDC values, where SEM (inter-rater) was $1,99^{\circ}$ and MDC 3,90․ SEM values were also analyzed by Hwang (2010)(Hwang et al., 2010), who found lower SEM values (below $2^{\circ}$ ) in angles of Cobb T12-S1, Cobb L1-L5 and L5-L1 posterior Tangent; values below 2.3응 were found in the method of the posterior Tangents T12-S1; and higher values of $2.3^{\circ}$ in the centroid T12-S1 method. Still, Troyanovich (1995)(Troyanovich et al., 1995), found SEM values intra-evaluator of posterior Tangent L1-L5 of $1.48^{\circ}$ to $1,58^{\circ}$ and inter-evaluator of 1,66 ${ }^{\circ}$ and Troyanovich (1998)(Troyanovich et al., 1998), who identified variations of SEM for Cobb T12-S1 and posterior TangentL1-L5, intra-evaluator of 1,99 to $3,32^{\circ}$ and $1,47^{\circ}$ to $1,88^{\circ}$ and inter-rater $2,67^{\circ}$ to $3,78^{\circ}$ and $1,40^{\circ}$ to $1,84^{\circ}$ respectively .

By analyzing the average values and SD of some studies, the Cobb showed higher standard deviations in comparison with the other method evaluated, as follows: Cobb T12-S1 with PR-T12(Chanplakorn et al., 2011), Cobb L1-S1 withTRALL(Chernukha et al., 1998), Cobb L1-L5 with TRALLL1-S1 and posterior Tangent L1-L5(Harrison, Cailliet, et al., 2001), Cobb L1-L5 and L1-S1 with TRALLL1-S1(Hong et al., 2010), Cobb L1-L5 and L1-S1 with TRALLL1-S1 and posterior Tangent L1-S1(Andreasen et al., 2007), Cobb T12-S1 with posterior Tangent L1-L5(Troyanovich et al., 1998). In contrast, the posterior tangent methods L1-L5 and Centroid L5-L1 showed higher DP values than the gold standard analyzed: Cobb L1-L5 and Cobb L1-S1(Lee et al., 2013b).

Each study sustains and discusses the use of certain methods according to their findings, which often contradict each other, but all corroborate in order to find the best method for evaluating lumbar lordosis. Harrison (2001)(Harrison, Harrison, et al., 2001) defends that the method of posterior Tangents and the Centroid are more recommended in the analysis of lumbar curvature for not using a potential source of error as the vertebral plateaus. Troyanovich (1998)(Troyanovich et al., 1998) supports the use of the posterior Tangents to be less susceptible to errors like those found in the Cobb, besides presenting lower SEM and acceptable ICCs.

Chanplakorn (2011)(Chanplakorn et al., 2011) and Gardocki (2002)(Gardocki et al., 2002) believe that lumbar lordosis is directly influenced by the magnitude degree of pelvic tilt, because they take into account the trunk imbalances, and therefore, the analysis of this segment is inevitable. They concluded that the PR measure can be useful to evaluate functional results of a spinal fusion in patients with sagittal imbalance. Jackson (1998) (Jackson et al., 1998a) reaffirms this importance when reports using the PR for evaluating lumbar lordosis, since it takes the sacrum and pelvis into consideration. The author describes these segments act as a sixth lumbar or pelvic vertebra to define a column arc. Jackson (2000) (Jackson et al., 2000b) states that the PR technique is more recommended to quantify the lumbar lordosis because it has good reproducibility, and can determine the sagittal pelvic imbalance through the hip. Also, even more important, because the PR and Cobb measures correlate and complement each other to settle lumbar lordosis.

When analyzing the reliability of an evaluation method, it is important to identify the mean absolute diffe- 
rence (MAD) of observers measures, which are determined to provide an error analysis, in that the higher the MAD values are, the greater the variability measure is.

The MAD inter-rater values verified in Lee's work (2013)(Lee et al., 2013b) were: centroid L1-L5 (7,1ํㅜ, TRALLL1-S1 $\left(6.4^{\circ}\right)$ and posterior Tangent L1-S1 (5,7우, all higher than the values found in the gold standard,

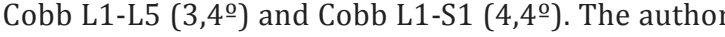
explains that all values were considered high, and attributes this to the fact that many people in the sample were suffering from ankylosing spondylitis, resulting in many irregularities in the vertebrae. In contrast, Chen (1999)(Chen, 1999) reports that the centroid method MAD has lower values and higher ICCs rates in comparison to Cobb, in healthy persons, and because of this, is more reproducible and recommended than the previous. Chernucka (1998)(Chernukha et al., 1998) proposes TREALL L1-S2 as a more reproducible method, which brings reductions between $8^{\circ}$ to $16^{\circ}$ of variability compared to Cobb L1-S1 values in adults. The author suggests that the Cobb depends on the quality and degree of image distortion, and may cause errors when scanning the lines of reference, because this method shows difficulties in choosing the vertebrae of references due to the wedge-shaped vertebral plateaus format, factors that do not affect TRALL, which uses the previous margins of the vertebral bodies, thus providing more reproducible values.

Regarding the evaluation of the lumbar spine in specific populations, individuals with severe scoliosis obtained a reduction in ICCs in both the Cobb and posterior Tangent methods in the level between L1-L5(Hong et al. 2010 ) in the control group. In contrast, Lee (2013)(Lee et al., 2013b) mentions that the sagittal evaluation of Cobb L1-L5 is more reproducible compared to the centroid L1-L5, posterior Tangents L1-S1 and L1-L5 and TRALLL1-S2 in individuals with this deformity. For some kind of spinal instability, such as spondylolisthesis, Hwag (2010)(Hwang et al., 2010) indicates the use of posterior Tangents in the evaluation of lumbar lordosis. Chernucka (1998)(Chernukha et al., 1998) describes that the quality and the degree of distortion of the radiographic image and wedge-shaped plateaus, features found in people with osteoporosis, osteomalacia, skeletal imaturation, disc herniation or espondiloarthrosis are factors that influence the Cobb angular formation and may overestimate or underestimate the angle of curvature. Therefore, the authors believe that the TRALL is more advantageous because it does not depend on the plateaus and has better reproducibility than the Cobb in the evaluation of the lumbar spine of children and adolescents(Chernukha et al., 1998).

Few studies that showed concurrent validity data lumbar lordosis between the proposed new method and Cobb(Gardocki et al., 2002; Pinel-Giroux, F. M. et al., 2006; Mac-Thiong et al., 2007; Vacari et al., 2015). Pinel-Giroux (2006)(Pinel-Giroux, F. M. et al., 2006) studied the maximum Cobb technique with tangential circles and found an $r=0.84$. The main advantage of tangential circles is that it provides a good alternative for evaluation of both the thoracic spine and the lumbar spine, because it allows evaluating the global geometry of the curves of the sagittal spine, especially when there is limited visibility on X-rays as it is not influenced the architecture and their deformities, not depending on the multiple identification markers along the curvature. This makes tangential circles less sensitive to digitization errors than Cobb, wherein an error in scanning a plateau, can significantly alter the magnitude of the curve.

Despite the not constricted Cobb technique take longer than Cobb, it shows better reproducibility rates, and the great advantage of this method is to take into account the variability in the level of transition between kyphosis and lordosis, allowing better assessment of the magnitude of curvatura(Mac-Thiong et al., 2007). The author found good correlation between Cobb L1-S1 methods with not constricted Cobb, demonstrated by an $r=0.94$. This method is concerned with the variation in the transition between the curvature of kyphosis and lordosis(Mac-Thiong et al., 2007), and that the column disorders treatments can affect the length of the back, for example, in spondylolisthesis.

Gardocki (2002)(Gardocki et al., 2002) correlated their method, the PR-L1 with Cobb L1-S1 and found an $r=0.82(0<0.001)$. The authors support the use of PR-L1, because it takes into account the lumbo-pelvic segment that can undergo modifications due to a poor sagittal balance, changing the lumbar lordosis. This finding is especially important in assessing patients with problems in this compensation, which are limited in some surgical procedures such as lumbar fusion, indicated in patients with flexion contracture of the hip or 
arthritis at this location, and depending on the degree of change, an analysis cautious about it, should be considered. Despite the lack of studies investigating these situations and relationships, they anticipate that the PR technique will be widely used in prediction of patient satisfaction and functional results after lumbar fusion and evaluation of patients with sagittal imbalance.

It is worth noting that most studies examined the adult population. Children, adolescents and the elderly who tend to have vertebral deformities were studied in only six of all studies found. The adults analyzed were not always healthy, therefore, also showing deformation or some difficulty in analyzing the vertebral levels to be assessed in many cases.

\section{CONCLUSION}

Of the 23 studies included in this review, only two did not present high methodological quality(Rajnics et al., 2001; Hicks et al., 2006). As for the reproducibility and repeatability, the Centroid, posterior Tangent and TRALL methods demonstrated equal or better reproducibility values and less variability of measures when compared to the Cobb angle. However, it is suggested that its use is confined to clinical monitoring, since they have no information on their validation, not being suitable for diagnostic measurements.

As to concurrent validity alternative methods: (1) in the thoracic region (Centroid T1-T12, tangential circles, alternative Cobb T4-T9, Radius of curvature, and not constricted Cobb) and (2) in the lumbar (PR-L1, tangential circles and not constricted Cobb) showed strong correlation with the gold standard (Cobb T1-T12). These results suggest that these methods are accurate and reliable for the evaluation of sagittal spinal column. 


\section{REFERENCES}

ADHIA, D. B. et al. Validity and reliability of palpation-digitization for non-invasive kinematic measurement-A systematic review. Manual therapy, v. 18, n. 1, p. 26-34, 2013. ISSN 1356689X.

ANDREASEN, M. L. et al. Reproduction of the Lumbar Lordosis: A Comparison of Standing Radiographs Versus Supine Magnetic Resonance Imaging Obtained with Straightened Lower Extremities. Journal of Manipulative and Physiological Therapeutics, v. 30, n. 1, p. 26-30, 2007. Disponível em: < http:// www.scopus.com /inward/record.url?eid $=2$-s 2.0 $-33846199097 \&$ partnerID $=40 \& \mathrm{md} 5=087 \mathrm{de} 9540 \mathrm{c} 51 \mathrm{c} 0 \mathrm{ff} 9 \mathrm{fdc}$ $351 \mathrm{~d} 77 \mathrm{e} 9 \mathrm{e} 831>$.

BERNHARDT, M.; BRIDWELL, K. H. Segmental analysis of the sagittal plane alignment of the normal thoracic and lumbar spines and thoracolumbar junction. Spine, v. 14, n. 7, p. 717-721, 1989. ISSN 0362-2436.

BIPM, I. et al. International vocabulary of metrology-basic and general concepts and associated terms, 2008. JCGM, v. 200, p. 99-12, 2008

BRIGGS, A. M. et al. Radiographic measures of thoracic kyphosis in osteoporosis: Cobb and vertebral centroid angles. Skeletal Radiology, v. 36, n. 8, p. 761-767, 2007. Disponível em: < http://www.scopus.com/inward/record.url?eid=2-s2.0-34347325289 \&partnerID $=40 \& \mathrm{md} 5=861498 \mathrm{e} 998 \mathrm{f} 177654 \mathrm{fc}$ $4 \mathrm{~b} 0 \mathrm{be} 5 \mathrm{c} 287 \mathrm{c} 3 \mathrm{f}>$

BRINK, Y.; LOUW, Q.; GRIMMER-SOMERS, K. The quality of evidence of psychometric properties of three-dimensional spinal posture-measuring instruments. BMC musculoskeletal disorders, v. 12, n. 1, p. 93, 2011. ISSN 1471-2474.

CARMAN, D.; BROWNE, R.; BIRCH, J. Measurement of scoliosis and kyphosis radiographs. Intraobserver and interobserver variation. J Bone Joint Surg Am, v. 72, n. 3, p. 328-333, 1990 ISSN 0021-9355.

CHANPLAKORN, P. et al. Lumbopelvic alignment on standing lateral radiograph of adult volunteers and the classification in the sagittal alignment of lumbar spine. European Spine Journal, v. 20, n. 5, p. 706-712, 2011. Disponível em:<http://www. s copus.com / in ward / r e cord.url? eid = 2 - s 2.0 $-79956204350 \&$ partnerID $=40 \& \mathrm{md} 5=0 \mathrm{f} 8 \mathrm{dd} 3115449$ aa $5 \mathrm{f} 7 \mathrm{ba}$ de6547b1850e5 >.

CHEN, Y. L. Vertebral centroid measurement of lumbar lordosis compared with the Cobb technique. Spine, v. 24, n. 17, p. 17861790, 1999. Disponível em: < http://www.scopus.com/ inward/record.url?eid=2-s2.0-0033200381\&partnerID $=40$ \& md5=139e8d2e73ee53872a2fed700b6d24cd >.

CHERNUKHA, K. V.; DAFFNER, R. H.; REIGEL, D. H. Lumbar lordosis measurement. A new method versus Cobb technique.
Spine (Phila Pa 1976), v. 23, n. 1, p. 74-9; discussion 79-80, Jan 1 1998. ISSN 0362-2436 (Print) 0362-2436.

GARDOCKI, R. J.; WATKINS, R. G.; WILLIAMS, L. A. Measurements of lumbopelvic lordosis using the pelvic radius technique as it correlates with sagittal spinal balance and sacral translation. Spine Journal, v. 2, n. 6, p. 421-429, 2002. Disponível em: < http://www.scopus.com/inward/record. url?eid=2-s2.0-0642378501\&partnerID $=40 \&$ md5=990518a5 3ea6af3252666cc0d3cebd03 >.

GOH, S. et al. A comparison of three methods for measuring thoracic kyphosis: Implications for clinical studies. Rheumatology, v. 39, n. 3, p. 310-315, 2000. Disponível em: < http:// www.s copus.com/inward / record. url? eid =2 -s 2.0 $-0034078406 \&$ partnerID $=40 \& \mathrm{md} 5=\mathrm{d} 2 \mathrm{bc} 0 \mathrm{c} 15 \mathrm{db} 5 \mathrm{fff} 877 \mathrm{c} 868$ 93d9a610022 >.

HARRISON, D. D. et al. Elliptical modeling of the sagittal lumbar lordosis and segmental rotation angles as a method to discriminate between normal and low back pain subjects. Journal of Spinal Disorders, v. 11, n. 5, p. 430-439, 1998. Disponível em: < http://www.scopus.com/inward/record.url?eid=2-s2.0-0031725309\&partnerID $=40 \& \mathrm{md} 5=\mathrm{d} 442 \mathrm{bc} 42 \mathrm{~d} 24 \mathrm{~d} 2 \mathrm{a} 0$ 83b87d8b57b1c8b22 >.

. Elliptical modeling of the sagittal lumbar lordosis and segmental rotation angles as a method to discriminate between normal and low back pain subjects. Clinical Spine Surgery, v. 11, n. 5, p. 430-439, 1998. ISSN 2380-0186.

HARRISON, D. E. et al. Reliability of centroid, Cobb, and Harrison posterior tangent methods: which to choose for analysis of thoracic kyphosis. Spine, v. 26, n. 11, p. e227-e234, 2001. ISSN 0362-2436.

. Radiographic analysis of lumbar lordosis: centroid, Cobb, TRALL, and Harrison posterior tangent methods. Spine, v. 26, n. 11, p. e235-e242, 2001. ISSN 0362-2436.

HICKS, G. E. et al. Measurement of lumbar lordosis: inter-rater reliability, minimum detectable change and longitudinal variation. J Spinal Disord Tech, v. 19, n. 7, p. 501-6, Oct 2006. ISSN 1536-0652 (Print) 1536-0652.

HIGGINS, J. P.; GREEN, S. Cochrane handbook for systematic reviews of interventions. John Wiley \& Sons, 2011. ISBN 1119964792 .

HONG, J. Y. et al. Reliability analysis for radiographic measures of lumbar lordosis in adult scoliosis: A case-control study comparing 6 methods. European Spine Journal, v. 19, n. 9, p. 15511557, 2010. Disponível em: < http://www.scopus.com/ inward/record.url?eid=2-s2.0-77956896840\& partnerID $=40$ \&md5 $=d 2922118 \mathrm{ad} 3194 \mathrm{f} 4 \mathrm{~b} 71 \mathrm{ca} 5 \mathrm{adf} 2 \mathrm{c} 0 \mathrm{e} 7 \mathrm{eb}>$.

HWANG, J. H. et al. Reliability of lumbar lordosis measurement in patients with spondylolisthesis: A case-control study com- 
paring the cobb, centroid, and posterior tangent methods. Spine, v. 35, n. 18, p. 1691-1700, 2010. Disponível em: < http:// www.scopus.com /inward / record.url?eid =2-s2.0$-77955983982 \&$ partnerID=40\&md5=fdd614a2334a0d9566 $5734603 \mathrm{ba} 57 \mathrm{f} 7 \mathrm{~d}>$

JACKSON, R. P. et al. Lumbopelvic lordosis and pelvic balance on repeated standing lateral radiographs of adult volunteers and untreated patients with constant low back pain. Spine, v. 25, n. 5, p. 575-586, 2000a. Disponível em: < http://www. scopus.com/inward/record.url?eid=2-s2.0-0034017629\&par tnerID $=40 \&$ md5 $=21 \mathrm{eb} 1 \mathrm{c} 28 \mathrm{~d} 17 \mathrm{adb} 0 \mathrm{~d} 2 \mathrm{~b} 825 \mathrm{e} 9051 \mathrm{f} 6 \mathrm{~b} 40 \mathrm{e}>$.

Lumbopelvic lordosis and pelvic balance on repeated standing lateral radiographs of adult volunteers and untreated patients with constant low back pain. Spine (Phila Pa 1976), v. 25, n. 5, p. 575-86, Mar 1 2000b. ISSN 0362-2436 (Print) 0362-2436.

Compensatory spinopelvic balance over the hip axis and better reliability in measuring lordosis to the pelvic radius on standing lateral radiographs of adult volunteers and patients. Spine (Phila Pa 1976), v. 23, n. 16, p. 1750-67, Aug 15 1998a. ISSN 0362-2436 (Print) 0362-2436.

Compensatory spinopelvic balance over the hip axis and better reliability in measuring lordosis to the pelvic radius on standing lateral radiographs of adult volunteers and patients. Spine, v. 23, n. 16, p. 1750-1767, 1998b. Disponível em: < http://www.scopus.com/inward/record.url?eid=2-s2.0-0032528869 \& partnerID $=40 \&$ md5=18ccfa1a1b2ddb1a 4511 $550799095 \mathrm{fbb}>$.

LEE, J. S. et al. Radiographic measurement reliability of lumbar lordosis in ankylosing spondylitis. Eur Spine J, v. 22, n. 4, p. 813-8, Apr 2013a. ISSN 0940-6719.

Radiographic measurement reliability of lumbar lordosis in ankylosing spondylitis. European Spine Journal, v. 22, n. 4, p. 813-818, 2013b. Disponível em: < http://www.scopus. com/inward/record.url?eid=2-s2.0-84892820286\&partnerI $\mathrm{D}=40 \& \mathrm{md} 5=5 \mathrm{f} 1 \mathrm{fd} 30 \mathrm{f} 1535 \mathrm{db} 00 \mathrm{fdabb} 3 \mathrm{dbca} 3 \mathrm{c} 88 \mathrm{~b} 2>$

MAC-THIONG, J. M. et al. Comparison between constrained and non-constrained Cobb techniques for the assessment of thoracic kyphosis and lumbar lordosis. European Spine Journal, v. 16, n. 9, p. 1325-1331, 2007. Disponível em: < http://www. scopus.com / in ward / r e cord.url ? e id $=2$ - s 2 . 0 $-34548582179 \&$ partnerID $=40 \& \mathrm{md} 5=16492 \mathrm{~b} 44432 \mathrm{de} 22 \mathrm{f} 54$ 045d841426c2e8 >.

MAY, S. et al. Reliability of physical examination tests used in the assessment of patients with shoulder problems: a systematic review. Physiotherapy, v. 96, n. 3, p. 179-190, 2010. ISSN 0031-9406.

PINEL-GIROUX, F.-M. et al. Computerized assessment of sagittal curvatures of the spine: comparison between Cobb and tan- gent circles techniques. Clinical Spine Surgery, v. 19, n. 7, p. 507-512, 2006. ISSN 2380-0186.

PINEL-GIROUX, F. M. et al. Computerized assessment of sagittal curvatures of the spine: Comparison between Cobb and tangent circles techniques. Journal of Spinal Disorders and Techniques, v. 19, n. 7, p. 507-512, 2006. Disponível em: < http://www.scopus.com/inward/record.url?eid=2-s2.0 $-33749530208 \&$ partnerID $=40 \&$ md5 $=385411 \mathrm{a} 202 \mathrm{a} 6 \mathrm{~b} 57 \mathrm{e} 17$ 95b7415b0a544f >

POLLY JR, D. W. et al. Measurement of lumbar lordosis: evaluation of intraobserver, interobserver, and technique variability Spine, v. 21, n. 13, p. 1530-1535, 1996. ISSN 0362-2436.

RAJNICS, P. et al. Computer-assisted assessment of spinal sagittal plane radiographs. Journal of Spinal Disorders, v. 14, n. 2, p. 135-142, 2001. Disponível em: < http://www.scopus. com/inward/record.url?eid=2-s2.0-0035057193\&partnerID $=40 \& \mathrm{md} 5=\mathrm{b} 7 \mathrm{ce} 0 \mathrm{~b} 4448 \mathrm{e} 81 \mathrm{c} 3429768 \mathrm{c} 4 \mathrm{e} 0555 \mathrm{f} 5 \mathrm{~d} 9$ > .

SHROUT, P. E.; FLEISS, J. L. Intraclass correlations: uses in assessing rater reliability. Psychological bulletin, v. 86, n. 2, p. 420, 1979. ISSN 1939-1455.

TROYANOVICH, S. J. et al. Further analysis of the reliability of the posterior tangent lateral lumbar radiographic mensuration procedure: Concurrent validity of computer- aided X-ray digitization. Journal of Manipulative and Physiological Therapeutics, v. 21, n. 7, p. 460-467, 1998. Disponível em: < http:// www.s copus.com / inward / record.url? eid = 2-s 2.0 -0031716663 \&partnerID $=40 \& \mathrm{md} 5=1 \mathrm{aef} 0113 \mathrm{e} 2864336139 \mathrm{c}$ $86 \mathrm{e} 27 \mathrm{~b} 12 \mathrm{c} 14 \mathrm{e}>$.

Intra-and interexaminer reliability of the chiropractic biophysics lateral lumbar radiographic mensuration procedure. Journal of manipulative and physiological therapeutics, v. 18, n. 8, p. 519-524, 1995. ISSN 0161-4754.

VACARI, D. A.; NEVES, E. B.; ULBRICHT, L. Comparison between methods of assessing lumbosacral curve obtained by radiographic image. Acta Ortopedica Brasileira, v. 23, n. 2, p. 67-71, 2015. Disponível em: < http://www.scopus.com/inward/record.url?eid=2-s2.0-84928991660\&partnerID $=40 \& \mathrm{md} 5=\mathrm{cbd}$ 4832905ab8fbe5a1d28ef108acc74 >.

ZAINA, C. et al. The effect of cervical rotation on blood flow in the contralateral vertebral artery. Man Ther, v. 8, n. 2, p. 103-9, May 2003. ISSN 1356-689X (Print) 1356-689x.

ČELAN, D. et al. Measurement of Spinal Sagittal Curvatures using the Laser Triangulation Method. Collegium Antropologicum, v. 36, n. 1, p. 179-186, 2012. Disponível em: < http:// www.s copus.com / inward / record.url? eid $=2$-s 2.0 $-84859465566 \&$ partnerID $=40 \& \mathrm{md} 5=77467 \mathrm{fba} 5 \mathrm{cc} 2482 \mathrm{ea} 39$ $8258668 \mathrm{fb} 0 \mathrm{fcb}>$ 